\begin{tabular}{|l|l|l|}
\hline \multicolumn{2}{|c|}{ PublisherInfo } \\
\hline \hline PublisherName & $:$ & BioMed Central \\
\hline \hline PublisherLocation & $:$ & London \\
\hline \hline PublisherImprintName & $:$ & BioMed Central \\
\hline \hline
\end{tabular}

\title{
Where do jaws come from?
}

\begin{tabular}{|l|l|l||}
\hline \multicolumn{2}{|c|}{ ArticleInfo } \\
\hline \hline ArticleID & $:$ & 4439 \\
\hline \hline ArticleDOI & $:$ & $10.1186 /$ gb-spotlight-20020403-02 \\
\hline \hline ArticleCitationID & $:$ & spotlight-20020403-02 \\
\hline \hline ArticleSequenceNumber & $:$ & 105 \\
\hline \hline ArticleCategory & $:$ & Research news \\
\hline ArticleFirstPage & $:$ & 1 \\
\hline \hline ArticleLastPage & $:$ & 2 \\
\hline \hline & & RegistrationDate : 2002-4-3 \\
\hline ArticleHistory & $:$ & OnlineDate \\
\hline \hline ArticleCopyright & $:$ & BioMed Central Ltd2002-4-3 \\
\hline \hline ArticleGrants & $:$ & \\
\hline \hline ArticleContext & $:$ & 130593311 \\
\hline \hline
\end{tabular}




\section{Jonathan B Weitzman}

Email: jonathanweitzman@hotmail.com

The origin of the vertebrate jaw is something of a mystery. In the March 28 Nature, Martin Cohn from the University of Reading suggests that Hox gene expression may be at the origin of jaw evolution (Nature 416:386-387). In jawed vertebrates (gnathostomes) the jaw and pharyngeal skeleton is derived from migrating cranial neural crest cells. Cohn studied the lamprey, a primitive jawless fish related to gnathostomes, in which the branchial arch is also neural-crest-derived. He cloned lamprey Hox genes and found gene expression in the mandibular arch (not seen in other vertebrates). He also noted a loss of Hox gene colinearity, as the HoxL6 expression domain extends anterior to the boundary of HoxL5. This loss of spatial colinearity was also seen in the cephalochordate amphioxus. As Hox gene expression can inhibit jaw formation, he proposes that loss of Hoxexpression in early gnathostomes may have facilitated the chondrification of the first arch crest that led to the formation of ventral madibular cartilage.

\section{References}

1. Nature, [http://www.nature.com]

2. University of Reading, [http://www.reading.ac.uk] 